\section{Late-onset atopic eczema and multiple food allergies after infectious mononucleosis}

Atopy is thought to be hereditary, though the mode of inheritance has not been completely established. It has been suggested ${ }^{1}$ that heredity is not the only important factor in the pathogenesis of the condition and that precipitating factors that modify immune regulation such as viral infections may also play a part. The following case may be an example of this.

\section{Case report}

A 22-year-old woman presented to her general practitioner in October 1976 with malaise and fever. Infectious mononucleosis was diagnosed and was confirmed by examination of a blood film and a positive Monospot test result. She had no history of skin problems or manifestations of atopy (including food allergy), and there was no family history of atopy.

Four weeks after the illness began the patient developed an erythematous itchy rash on her face, which spread to the cubital and popliteal fossae, presenting the typical appearance of atopic eczema. Six months later, after eating an egg, she developed angio-oedema with swelling of the mouth and face, which lasted several hours. She was advised to avoid eggs and referred to hospital. Skin prick tests with Bencard allergens elicited no positive reactions to int.alants (grass, pollens, cat and dog fur, house dust, and housedust mite) or foods (milk, egg, cheese, fish, shellfish, wheat, mixed vegetable, mixed meats, and mixed fruits). Total serum IgE concentration (double antibody method ${ }^{2}$ ) was raised at $2150 \mathrm{U} / \mathrm{ml}$, but radioallergosorbent tests (RAST; Pharmacia, Uppsala, Sweden) to three inhalants and 10 foods (egg, milk, fish, wheat, peanut, hazelnut, Brazil nut, almond, crab, and shrimp) elicited a positive result only to cat fur (table). There were no other findings of note apart from flexural eczema.

The eczema continued but she had no further angio-oedema until October 1979, when she had an episode after drinking cows' milk. After this her eczema worsened and she was advised to avoid cows' milk. In December 1979 she had a further episode of angio-oedema accompanied by asthma after eating cheese, and in February 1980 a similar episode occurred after taking goats' milk, which had been recommended as a substitute for cows' milk. By that time she was showing positive skin-prick reactions to grass pollens, cat and dog fur, and house dust, as well as to milk, egg, and cheese. She was also giving strongly positive results in radioallergosorbent tests (Phadebas RAST score system, 0-4) with cat fur, egg, cows' milk, and cheese (table).

Total serum IgE concentrations and radioallergosorbent test scores, fune 1977 to September 1980. (Radioallergosorbent test scores of 2-4 considered positive)

\begin{tabular}{|c|c|c|c|c|c|}
\hline \multirow{2}{*}{ Date } & \multirow{2}{*}{$\begin{array}{c}\text { Total } \\
\text { IgE } \\
(\mathrm{U} / \mathrm{ml})\end{array}$} & \multicolumn{4}{|c|}{ Radioallergosorbent test scores } \\
\hline & & Cat fur & Egg & Milk & Cheese \\
\hline $\begin{array}{l}\text { June } 1977 \\
\text { October } 1978 \\
\text { June } 1979 \\
\text { January } 1980 \\
\text { June } 1980 \\
\text { September } 1980\end{array}$ & $\begin{array}{l}2150 \\
5100 \\
3900 \\
6200 \\
5800 \\
7230\end{array}$ & $\begin{array}{l}3 \\
3 \\
3 \\
3 \\
3 \\
4\end{array}$ & $\begin{array}{l}1 \\
3 \\
3 \\
3 \\
2 \\
2\end{array}$ & $\begin{array}{l}0 \\
2 \\
3 \\
4 \\
4 \\
4\end{array}$ & $\begin{array}{l}0 \\
2 \\
2 \\
3 \\
3 \\
3\end{array}$ \\
\hline
\end{tabular}

During the next six months she had frequent episodes of angio-oedema without obvious cause and the total serum IgE concentration increased to $7230 \mathrm{U} / \mathrm{ml}$. She therefore began oral sodium cromoglycate (Nalcrom) in October, 1980, with apparent improvement initially. In December, however, despite advice to the contrary, she ate macaroni cheese, which precipitated a severe episode of angio-oedema accompanied by bronchospasm, necessitating treatment with intravenous hydrocortisone and chlorpheniramine. Despite increasing the dose of sodium cromoglycate she had further exacerbations of the eczema on her face and in the flexures with episodes of angio-oedema. She continued to pose a considerable management problem.

\section{Comment}

Most patients with atopic eczema develop the condition during the first two years of life, but on occasion it may present later: our patient developed the condition during adulthood. The causal relation between food allergy and atopic eczema remains controversial. A recent doubleblind controlled cross-over study ${ }^{3}$ showed that out of 20 children with atopic eczema aged 2-8 years, most responded more favourably to a diet which excluded cows' milk and eggs, though there was not complete clearing of the skin condition.

Our patient was interesting not because she developed atopic eczema in early adulthood but because it appeared soon after an episode of infectious mononucleosis, which being a viral infection of lymphocytes might well upset mechanisms of immune regulation. This would accord with Katz's hypothesis of "allergic breakthrough," and certainly in children viral infections have been associated with the first manif stations of atopy. ${ }^{4}$ Our patient's atopic eczema presented several months before the manifestations of food allergy, and this is backed up by the results of prick tests and radioallergosorbent tests this might argue against the possibility that atopic eczema and food allergy are causally related but rather that both may result from lack of immunosuppression, which has been shown to be a feature of atopy. ${ }^{5}$

${ }^{1}$ Katz DH. The allergic phenotype. Manifestation of "allergic breakthrough" and imbalance in normal "damping" of IgE antibody production. Immunol Rev 1978; $1: 77-108$.

${ }^{2}$ Merrett TG, Pantin (, A. Increasing the precision and speed of the separation step in radio-in munoassays. Clin Chim Acta 1975;65:131-4.

${ }^{3}$ Atherton DJ, Sew ell $\mathrm{i}$, Soothill JF, Wells RS, Chilvers CED. A double blind controlled cross-over trial of an antigen-avoidance diet in atopic eczema. Lancet 1978 ; : $: 401-3$.

' Frick OL, German DF, Mills J. Development of allergy in children. Association with virus infections. F Allergy Clin Immunol 1979;63: 228-41.

${ }^{5}$ Strannegard IL. Lymphocyte stimulation with phorbol myristate acetate in atopic and non-atopic individuals. Int Arch Allergy Appl Immunol $1979 ; 58: 175-81$.

(Accepted 15 fuly 1981)

Department of Dermatology, Royal Infirmary, Edinburgh EH3 9YW R STC BARNETSON, MD, MRCP, consultant dermatologist

$R$ A HARDIE, MRCP, lecturer in dermatology

RAST Allergy and Research Unit, Benenden, Kent

T G MERRETT, PHD, director

\section{Renal embolisation for urinary fistula caused by irreparable ureteric injury}

Urinary leakage from ureteric damage during colonic surgery is a rare complication. In two elderly poor-risk patients not fit for further surgery it was successfully stopped by transfemoral catheterisation of the appropriate renal artery and embolisation of the kidney.

\section{Case reports}

CASE 1

An 84-year-old woman presented with left iliac fossa pain, constipation, and weight loss over two months. Examination showed a hard mass in the left iliac fossa and barium enema confirmed a carcinoma of the sigmoid colon.

At operation an extensive colonic tumour affecting the left ureter was found. This was divided and ligated with two ligatures during the resection of the growth. A Hartmann operation was performed with closure of the rectal stump and formation of end colostomy. A drain was inserted into the left iliac fossa. Urinary leakage occurred on the third postoperative day and continued with volumes ranging from 500 to $900 \mathrm{ml}$ urine a day. Intravenous pyelography confirmed a leak from the left ureter. In view of her age and frail condition surgery was not justified, but three weeks after the original operation, under local anaesthetic, the right femoral artery was catheterised and a catheter manipulated into the left renal artery. This was embolised with Gelfoam and a wire spring to achieve permanent occlusion. Urinary leakage ceased immediately and there were no sequelae. The patient was discharged to a nursing home three weeks later.

CASE 2

A 66-year-old man was admitted with diarrhoea, abdominal pain, and weight loss of six months' duration. Barium enema showed a malignant 